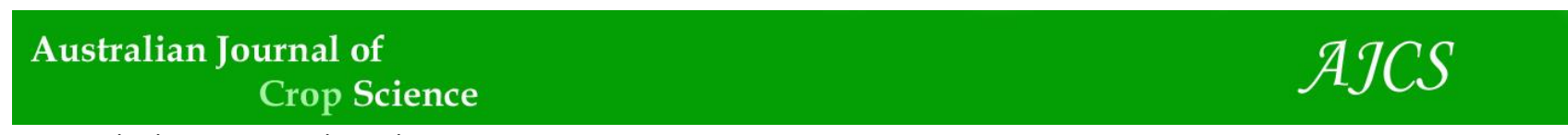

AJCS 11(09):1116-1122 (2017)

ISSN:1835-2707

doi: 10.21475/ajcs.17.11.09.pne531

\title{
Attributes of growth, physiological quality and isoenzymatic expression of common bean seeds produced under the effect of gibberellic acid
}

\author{
Cristian Troyjack ${ }^{1}$, Ítala Thaísa Padilha Dubal ${ }^{1}$, Felipe Koch $^{1}$, Vinícius Jardel Szareski ${ }^{1}$, João Roberto \\ Pimentel $^{1}$, Ivan Ricardo Carvalho ${ }^{1}$, Maicon Nardino ${ }^{1}$, Gustavo Henrique Demari ${ }^{1}$, Francine \\ Lautenchleger $^{2}$, Velci Queiróz de Souza ${ }^{3}$, Francisco Amaral Villela ${ }^{1}$, Tiago Zanatta Aumonde ${ }^{1}$, Tiago \\ Pedó $^{1}$
}

\author{
${ }^{1}$ FederalUniversityof Pelotas, CEP 96010-610, Capão do Leão, RS, Brazil \\ ${ }^{2}$ FederalUniversityof Santa, Santa Maria, RS, Brazil \\ ${ }^{3}$ FederalUniversityof Pampa, Dom Pedrito, RS, Brazil
}

*Corresponding author: viniciusszareski@gmail.com

\begin{abstract}
The gibberellins (GA) present an essential role in many aspects of plant development, seed germination, internode elongation, flower and fruit development. Thus, this work aimed to evaluate the growth attributes and the physiological quality of bean seeds from plants submitted to the application of gibberellic acid, revealing great importance in some characters of agronomic interest. Seeds of genotypes (Phaseulus vulgaris) Mouro and BRS Embaixador and four concentrations of gibberellic acid (zero, 50, $100 \mathrm{and} 200 \mathrm{mg}$ $\mathrm{L}^{-1}$ ) were used. Seed germination, first count, germination speed, primary root and shoot length, dry matter of seedlings, shoot height, stem diameter, first pod insertion, pod number and seeds per pod were evaluated. Giberelic acid promoted an increase in plant height and a reduction in stem diameter. Seeds produced under doses of $\mathrm{GA}_{3}$ did not influence seed germination and dry matter of the seedlings at higher doses, being dependent on the cultivar. In this way, the application of increasing doses of $\mathrm{GA}_{3}$ in bean plants increases the height of insertion of the first pod, while the physiological quality of the seeds produced is affected by the acid doses.
\end{abstract}

Keywords: Phyto-Regulator, Phaseolus vulgaris, Plant Architecture. Abbreviations: GA_Gibberellins; $\mathrm{GA}_{3}$ Gibberellic acid.

\section{Introduction}

Bean cultivation (Phaseolus vulgaris L.) has significant economic and social importance in Brazil. The cultivated area covers about 3.0 million hectares, with an approximate production of 3.3 million tons of grains, corresponding to a yield close to $1079 \mathrm{~kg} \mathrm{ha}^{-1}$. In this scenario, the Southern Region stands out with approximately $50 \%$ of the total production in the 2015/2016 harvest (Conab, 2016). The increase in productivity is becoming essential in the exploration of this culture through the interaction between the environmental, genetic and mainly, management techniques and the use of high quality seeds (Bototti et al., 2008). However, the architecture of the bean plants constitutes a problem, especially regarding to the low height of insertion of the first pod, being necessary to promote the elongation of the basal internodes and consequently the insertion of the pods, in order to enable improvements in the mechanized harvest (Souza et al., 2010). The use of growth regulators has brought perspectives to increase productivity and quality in products of plant origin in different cultures (Khan et al., 2006).The application of gibberellin on plants can be a strategy to increase the insertion height of the pods, as it promotes an increase in the distance of the internodes closest to the soil (Vichiato et al., 2007). Among the groups of growth regulators, gibberellin has a marked effect on the seed germination process, activating hydrolytic enzymes, such as $\alpha$-amylase and protease, that actively act in the unfolding of the reserve substances, facilitating the mobilization of the endosperm (George et al., 2008). In addition, it plays an important role in the development and physiological actions of plant tissues, gibberellic acid acts directly on tissue differentiation (Duan; 1999; Mosquim, 2004; Amarante et al., 2005; DoNascimento; Ju; Khan et al. 2006). Giberelins are responsible for several important physiological functions in the development of superior plants (Hooley 1994, Lange 1998). According to Taiz and Zeigler (2004), the application of gibberellin provides the elongation of internodes in several species being the meristem intercalary the action target, which is located near the base of the internode, that produces derivatives that go up and down, in this way, the exogenously applied $\mathrm{GA}_{3}$ causes excess stem elongation in dwarf plants, so that the plants resemble the higher varieties of the same species. Among the most well-known functions, it can be highlighted the mobilization of seed reserves in germinating cereals and the promotion of stem elongation in some species. Depending on the plants, gibberellins may also be required for leaf expansion, floral induction, anthocyanin biosynthesis (Khan et al., 2006) and development of immature fruits (Garcia-Martinez et al., 1987; Graebe et al., 1987; Van Huizen et al. Al., 1997) and even in the control of physiological disturbances (Amarante et al., 2005). The correct timing of the application of plant regulators is still not fully defined, due to several factors that may influence this process, such as climatic conditions, which are obviously different from year to year, and promote changes in the stage 
of development of each plant. Therefore, the responses expected from plant regulators can be quite variable, especially when the recommendations are transferred from one place to another, where the difficulties become more accentuated. The cultural conditions such as soil type, pest control, nutritional aspects and water-plant atmosphere relationships interact also influence the results obtained with plant regulators (Monselise, 1979).

In view of the above, this work aimed to evaluate the growth attributes, the physiological and isoenzymatic quality of bean seeds from plants submitted to the application of gibberellic acid.

\section{Results and Discussion}

Referring to the growth attributes of genotypes under the effect of gibberellic acid, it was observed by the analysis of variance that there was interaction between genotypes $\mathrm{x}$ doses of $\mathrm{GA}_{3}$ for the variables plant height, stem diameter and insertion of the first pod. This study demonstrated that gibberellic acid altered parameters related to the architecture of bean plants in both genotypes.

The stem diameter of both genotypes tended to decrease as a function of $\mathrm{GA}_{3}$ dose increase (Fig 1A). For the genotypes Mouro and BRS Embaixador, the doses of $\mathrm{GA}_{3}$ that caused the smallest diameter of the stem were 130 and $200 \mathrm{mg} \mathrm{L}^{-1}$, respectively.

The plant height of both genotypes was adjusted to the quadratic model, with an expressive coefficient of determination $\left(\mathrm{R}^{2} \geq 0.75\right)$ (Fig $\left.1 \mathrm{~B}\right)$. For both genotypes, it was observed that the increase of the dose of $\mathrm{GA}_{3}$ caused an increase in the height of the plants, and the highest height was observed with the dose of $200 \mathrm{mg} \mathrm{L}^{-1}$ of $\mathrm{GA}_{3}$ (Fig 1B). This response can be attributed to gibberellic acid to induce differentiation of meristematic cells (Taiz\&Zeiger, 2009), which was probably responsible for the increase in bean plant height.

The number of pods per plant increased for Mouro genotype at higher doses, while at the dose of $200 \mathrm{mg} \mathrm{L}^{-1}$ of $\mathrm{GA}_{3}$ there was a reduction in the number of pods in the BRS Embaixador (Fig 1C). Mouro genotype presented higher number of pods per plant, compared to BRS Embaixador, at all doses evaluated. However, the number of seeds per pod of both genotypes tended to decrease with increasing $\mathrm{GA}_{3}$ dose (Fig 1D).

The height of insertion of the first pod of both genotypes was adjusted to the quadratic model, being obtained with a high coefficient of determination $\left(\mathrm{R}^{2} \geq 0.82\right)$ (Fig 1E). The application of $\mathrm{GA}_{3}$ increased the height of insertion of the first pod in the plants of both genotypes, and the genotype BRS Embaixador showed higher height of insertion of the first pod in all doses of $\mathrm{GA}_{3}$ evaluated, compared to Mouro. The maximum height of insertion of the first pod in the genotypes BRS Embaixador and Mouro occurred with the doses of 164.0 and $140.6 \mathrm{mg} \mathrm{L}^{-1}$ of $\mathrm{GA}_{3}$.

Concerning the physiological and isoenzymatic quality of seeds produce, it was verified that the germination of bean seeds of the genotypes Mouro and BRS Embaixador produced under the effect of gibberellic acid on the plants, showed a tendency to increase until the doses of 114.1 and $91.5 \mathrm{mg} \mathrm{L}^{-1}$ of $\mathrm{GA}_{3}$, respectively (Fig $2 \mathrm{~A}$ ). It was observed that at doses zero and $200 \mathrm{mg} \mathrm{L}^{-1}$ of $\mathrm{GA}_{3}$, the seeds of the genotype Mouro presented lower germination, compared to the BRS Embaixador genotype.

The first germination count was adjusted to the quadratic polynomial model and obtained with a high coefficient of determination $\left(\mathrm{R}^{2} \geq 0.93\right)$ (Fig $\left.2 \mathrm{~B}\right)$. The first germination count for Mouro genotype increased up to the $91.5 \mathrm{mgL}^{-1}$ dose, while for BRS Embaixador there was a decrease in this attribute as a function of the $\mathrm{GA}_{3}$ dose increase. Thus, it is possible to detect that the genotypes present different behavior in function of the different doses of $\mathrm{GA}_{3}$ applied on the plants. However, the germination speed index presented a maximum and minimum behavior for the genotypes Mouro and BRS Embaixador (Fig 2C), with values of 152.5 and $158.5 \mathrm{mgL}^{-1}$ for Mouro and BRS Embaixador, respectively.

The shoot length values of both genotypes were adjusted to the quadratic model, both of which showed a tendency to increase, as a function of the $\mathrm{GA}_{3}$ dose increase (Fig 2D). Both Mouro and BRS Embaixadorgenotypes reached the maximum seedling length when the $200 \mathrm{mg} \mathrm{L}^{-1}$ dose of $\mathrm{GA}_{3}$ was used on the plants. For the main root length, it was observed that the genotype BRS Embaixador showed values higher than Mouro, at all doses evaluated (Fig 2E). Both genotypes tended to increase the length of the main root, due to the increase of the dose of gibberellic acid.

The total dry mass of seedlings adjusted to the quadratic polynomial model (Fig 2F). For the Mouro genotype, the maximal point occurred with the use of the $200 \mathrm{mg} \mathrm{L}^{-1}$ dose of $\mathrm{GA}_{3}$, whereas for BRS Embaixador genotype, this occurred when $60.1 \mathrm{mg} \mathrm{L}^{-1}$ of $\mathrm{GA}_{3}$ was used. In general, small variation in the dry mass of the seedlings of both genotypes is observed as a function of the doses of $\mathrm{GA}_{3}$ used in the vegetative stage of the plants.

The expression of the esterase isoenzyme in the aerial part of the seedlings ofMouro genotype, when the plants were submitted to a dose of $100 \mathrm{mg} \mathrm{L}^{-1}$, resulted in the expression of four esterase alleles (EST1; EST2; EST3; EST4); while with the use of the other doses, only three alleles of this enzyme (EST1; EST2; EST3) were expressed in the aerial part (Fig 3). In BRS Embaixador genotype, all the doses evaluated resulted in the expression of three esterase isozyme alleles (EST1; EST2; EST3), with the highest intensity observed in EST1 and EST3 in the aerial part (Fig 3).

In the roots of the seedlings of Mouro genotype, all the doses of gibberellic acid resulted in the expression of three esterase isozyme alleles (EST1; EST2; EST3), with the highest intensity of the bands observed in the alleles (EST2; EST3) (Figure 3). In BRS Embaixador genotype, the use of 100 and $200 \mathrm{mg} \mathrm{L}^{-1}$ doses of gibberellic acid resulted in the expression of three esterase isozyme alleles (EST1; EST2; EST3). In this same genotype, the use of zero doses and 50 $\mathrm{mg} \mathrm{L}^{-1}$ resulted in the expression of only two alleles of esterase isozyme (EST2; EST3), which were of low intensity when the $50 \mathrm{mg} \mathrm{L}^{-1}$ dose was used.

The acid phosphatase isoenzyme presented higher intensity in the bands for the aerial part of the plant in relation to the root in both evaluated genotypes (Fig 4). For the two genotypes, the expression of only one acid phosphatase allele $(F A C l)$ was observed in all evaluated doses, being the highest intensity of it observed with the use of $200 \mathrm{mg} \mathrm{L}^{-1}$ of gibberellic acid.

When the isoenzymatic expression of acid phosphatase in seedlings roots was evaluated, both genotypes, independent of the dose used, showed the expression of two alleles of this isoenzyme (FAC1; FAC2) (Fig 4). In BRS Embaixador genotype, the expression intensity of the acid phosphatase isoenzyme performed in the root of the seedlings through the $F A C 1$ and FAC2 bands was reduced with the use of the 50 $\mathrm{mg} \mathrm{L}^{-1}$ dose of gibberellic acid, compared to the other doses evaluated.

In Mouro genotype, for $F A C l$, evaluated in the roots, no difference in the intensity of the bands occurred as a function of the dose increase, whereas for $F A C 2$ the highest intensity 

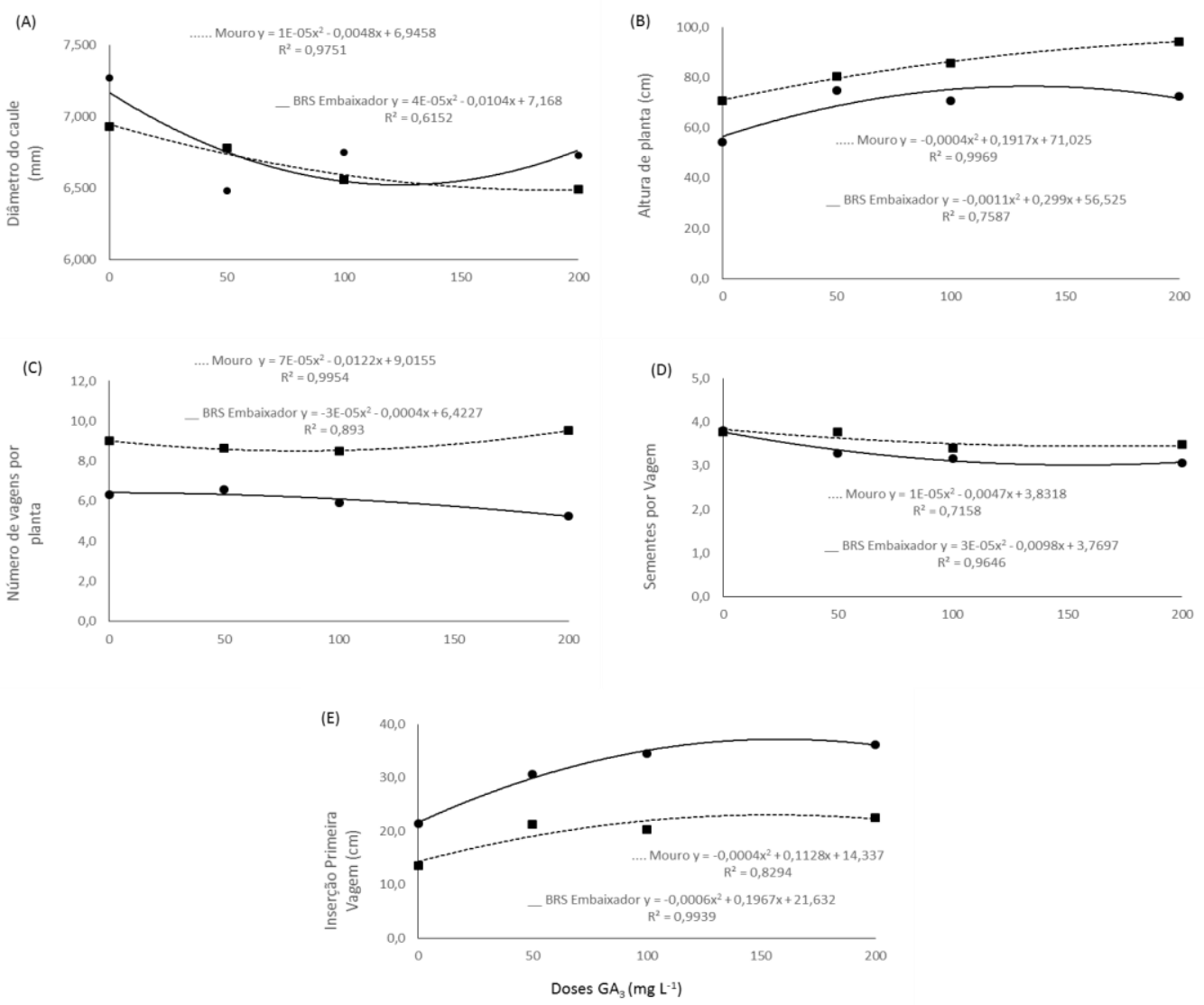

Fig 1. Stem diameter (A); Plant height (B); Number of pods per plant (C); Seedlings per pod (D) and first pod insertion (E) in bean plants of the genotype Mouro $(\cdot)$ and cultivar BRS Embaixador $(\bullet)$, submitted to different doses if $\mathrm{GA}_{3}$
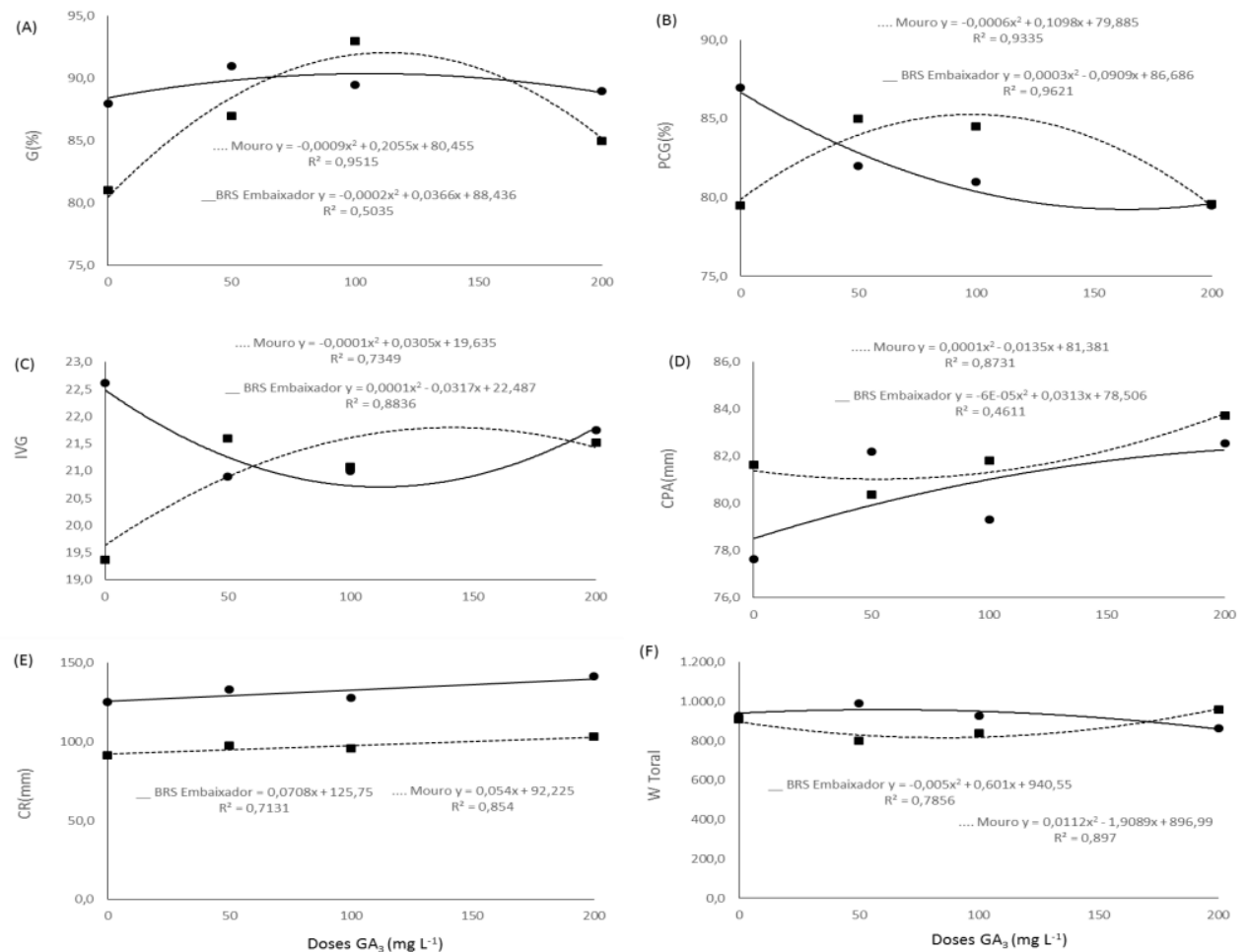

Fig 2. Germination (G) (A); First germination count (FGC) (B); Germination speed index (GSI) (C); Length of aerial part ( $\left.\mathrm{L}_{\mathrm{AP}}\right)(\mathrm{D})$; Primary root of seedlings $\left(\mathrm{L}_{\mathrm{R}}\right)(\mathrm{E})$ and total dry mass $(\mathrm{Wt})$ of the genotypes Mouro $(\cdot)$ and BRS Embaixador $(*)$ produced under the effect of different doses of $\mathrm{GA}_{3}$ applied in the $\mathrm{V}_{2}$ stage. 


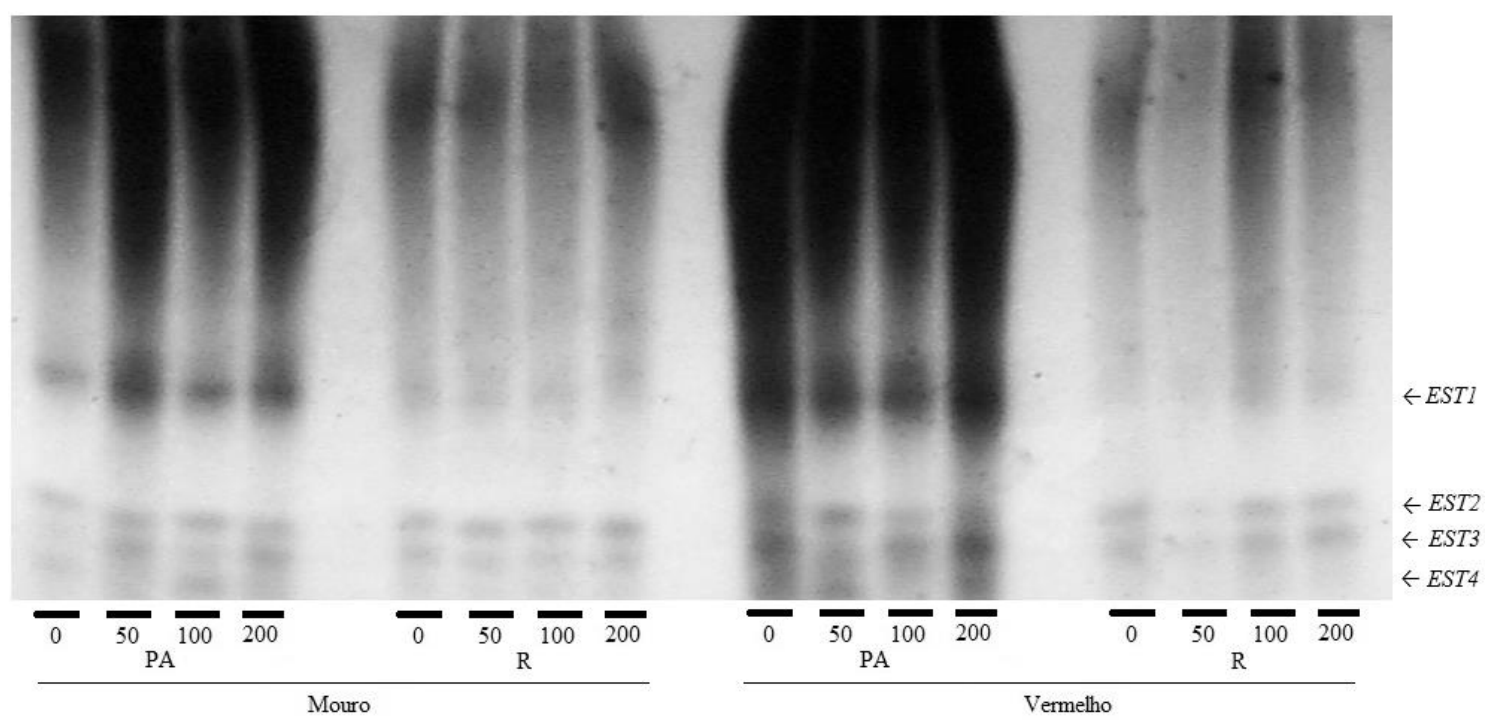

Fig 3. Expression of the esterase isoenzyme in bean seedlings of the genotypes BRS Embaixador (Vermelho) and Mouro, submitted to the cold test and the application of four doses of $\mathrm{GA}_{3}(0,50,100$ and 200) evaluated in aerial part (AP) and Root $(\mathrm{R})$ of seedlings originated from seeds produced under the effect of different doses of $\mathrm{GA}_{3}$ applied in the $\mathrm{V}_{2}$ stage of the plants.

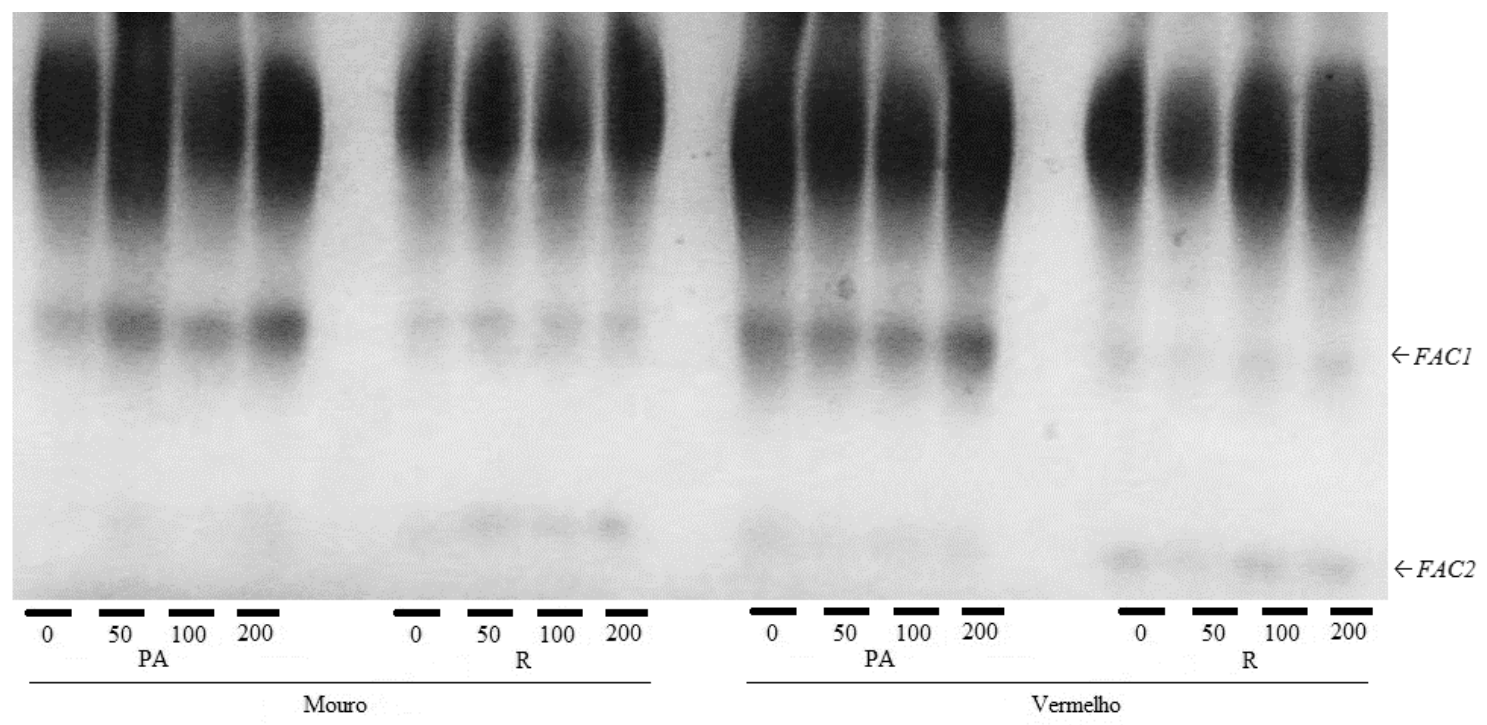

Fig 4. Expression of the acid phosphatase isoenzyme in bean seedlings of the genotypes BRS Embaixador (Vermelho) and Mouro, submitted to the cold test and he application of four doses of $\mathrm{GA}_{3}(0,50,100$ and 200) evaluated in aerial part (AP) and root (R) of seedlings originated from seeds produced under different doses of $\mathrm{GA}_{3}$ applied in the $\mathrm{V} 2$ stage of plants.

of expression was observed with the dose of $200 \mathrm{mg} \mathrm{L}^{-1}$ (Fig 4).

\section{Discussion}

The reduction in stem diameter in bean plants is attributed to cell elongation as the applied doses are increased. Studies with $\mathrm{GA}_{3}$ demonstrate a relationship in diameter reduction with increased stature induced by the application of this regulator (Leite et al., 2003).

For the height of plants the increase of the GA3 dose caused gains. This response can be attributed to gibberellic acid to induce differentiation of meristematic cells (Taiz\&Zeiger, 2009), which was probably responsible for the increase in bean plant height.Giberelic acid $\left(\mathrm{GA}_{3}\right)$ is one of the most used to manipulate plant growth, promote stem growth, stimulate cell expansion and division, and accentuate the expression of apical dominance in plants (Weiss, 2007). Its application promotes the lengthening of internodes (Taiz\& Zeigler, 2013). Thus, it can be used to increase the extension of the basal internodes of the bean plants and consequently the height of insertion of the pods, and this way, it can provide benefits in the mechanized harvest of beans.

The increase of the height of the first pod insertion may be related to the increase of the height of the plants, promoted by the increasing application of $\mathrm{GA}_{3}$ doses, which influenced the elongation of the basal internodes. According to Sauter\&Kende (1992), this elongation response of internodes is based on the expansion of cells of the intercalary meristem, which, by increasing the cell division, allows an increase in the height of the plant. These results corroborate with those 
found by Leite et al. (2003), with the increase in stem height in soybean plants under the effect of gibberellic acid.

When gibberellic acid is applied before flowering, it induces an intense vegetative growth, which allows a greater accumulation of photosynthesized, which are directed to the vegetative growth that, in detriment, increase the quality of the reproductive structures (Leite et al., 2003). The application of exogenous $\mathrm{GA}_{3}$ in plants, in addition to altering the architecture attributes of the plants, contributes to the greater uptake of the solar energy absorbed by the canopy (Sun; Gubler, 2004), helping the plant and leaf architecture, improving the utilization of light through the canopy, favoring the physiological quality of the seeds produced.

The esterase isozyme presents itself as an important molecular tool that allows evaluating the physiological quality of the seeds (Albuquerque et al., 2010). This is related to the ester hydrolysis reactions, maintaining a direct relationship with the lipid metabolism and the degeneration process of the cell membranes (Santos et al., 2004). The presence of lipids during the germination process of the seeds is important for the restoration of embryonic axis growth (Veiga et al., 2010).

In this sense, the expression of the esterase isoenzyme, verified in both genotypes in the seedling structures (shoot and root) with the respective doses applied in the mother plants, possibly demonstrates the occurrence of the physiological quality of the seeds produced. Behavior that can be affirmed in the germination data previously demonstrated.

Acid phosphatase presents significant importance during the germination and initial growth of the species (Pedóet al., 2015), as it acts on the remobilization of inorganic phosphate during the germination process (Granjeiro et al., 2008). In addition, in many cases this isoenzyme may be associated with esters hydrolysis reactions, which may lead to peroxidation of membrane phospholipids (Cruz et al., 2007). Thus, the low expression intensity, as well as acid phosphatase isoenzyme bands in both genotypes, shoot and root, may possibly be related to the occurrence of moderate lipid peroxidation in the seeds of this species, thus allowing the maintenance of the high physiological quality of the seeds.

The results observed in the present study demonstrate that the use of $\mathrm{GA}_{3}$ provides positive effects on some plant growth attributes, such as plant height and height of the first pod insertion, which possibly enabled an increase in the physiological quality of the seeds observed mainly through root and shoot length test. In this way, these results help consequently in the decision made by the farmers, providing information of extreme importance for the improvement of the agronomic performance of the bean crop.

\section{Materials and Methods}

The experiment was carried out at the Campus of the Federal University of Pelotas, EliseuMaciel Agronomy College, Capão do Leão, Rio Grande do Sul, Brazil, and the analyzes were carried out in the laboratory of Seed Physiology.

The experimental design was a completely randomized, organized in a $4 \times 2$ factorial scheme, with four replicates of gibberellic acid $\left(\mathrm{C}_{19} \mathrm{H}_{22} \mathrm{O}_{6}\right)\left(0,50,100\right.$ and $\left.200 \mathrm{mg} \mathrm{L}^{-1}\right)$ and two genotypes (BRS Embaixador and Mouro) with 12 replicates. The treatments were applied in the $\mathrm{V}_{2}$ stage (fully opened primary leaves). The application was carried out via foliar and by pressurized rod sprayer with $\mathrm{CO}_{2}$ and flat fan sprays (110-020), with a $50 \mathrm{~L} \mathrm{ha}^{-1}$ spray volume.
The seeds were arranged to germinate and the seedlings to be grown in polyethylene vessels with volumetric capacity of 20 liters, containing as substrate, soil the of a Salic EutricHaplicPlanosol, belonging to the Pelotas mapping unit (Streck et al., 2008), previously Corrected, according to its analysis, and based on the Manual of Fertilization (CQFS RS / SC, 2004). The evaluations were divided into two stages:

\section{Evaluation of growth attributes of the genotypes under the effect of gibberellic acid}

For the growth assessment the following analyzes were carried out:

Diameter of the stem (D): it was determined with the aid of a digital caliper, the results being expressed in millimeters.

Height of the plants: determined with the aid of tape measure, being measured from the insertion of the roots to the stem end, and the results are expressed in centimeters.

Number of pods (NPg): obtained by direct counting, expressed in number of pods per plant.

Number of seeds per pod (NSm / Pg): determined by dividing the total number of seeds by the total number of pods, the results being expressed in number of seeds per pod.

Height of insertion of the first pod: determined with the aid of tape measure, being checked from the insertion of the roots to the insertion of the first pod, being the results expressed in centimeters.

\section{Evaluation of the physiological and isoenzymatic quality of the seeds produced}

In order to evaluate the physiological quality of the seeds produced from plants submitted to gibberellic acid, the seeds were harvested and benefited by hand, and were then sent to the laboratory, where the following evaluations were carried out:

Germination test (G): carried out in four samples, with four subsamples of 50 seeds, arranged to germinate in rolls formed by three sheets of germitest paper, moistened with distilled water in the proportion 2.5 times the dry mass of the paper. After the linear arrangement of the seeds on the leaves, they were rolled to form rolls, which were later transferred to the germination chamber type B.O.D. at $25^{\circ} \mathrm{C}$ and luminous period of $12 \mathrm{~h}$. The evaluations were carried out nine days after sowing, and the results were expressed as percentage of normal seedlings, according to the Rules for Testing Seeds (BRASIL, 2009).

\section{First germination count (FGC):}

carried out in conjunction with the germination test, counting at five days after sowing, according to the Rules for Testing Seeds (BRASIL, 2009). The results were expressed as percentage of normal seedlings.

\section{Germination speed index (GSI):}

obtained from daily germinated seed counts (minimum radicular protrusion from 3 to $4 \mathrm{~mm}$ ). The counts were performed until the constant number of germinated seeds was obtained. TheGSIwas calculated according to Vieira \&Carvalho (1994). 
Length of aerial part $\left(\mathrm{L}_{\mathrm{AP}}\right)$ and primary root of seedlings $\left(\mathbf{L}_{\mathbf{R}}\right)$ : obtained from four samples of 10 seedlings at the end of the germination test. The aerial part length was obtained by measuring the distance between the insertion of the basal portion of the primary root to the apex of the aerial part, while the length of the primary root was determined by measuring the distance between the apical and basal part of the primary root. The results were expressed in $\mathrm{mm}_{\text {organ }}{ }^{-1}$.

Total dry mass (Wt): obtained by measuring the mass of four samples of 10 seedlings at the end of the germination test. The seedlings were conditioned in brown paper envelopes and submitted to oven drying with forced ventilation at $70^{\circ} \mathrm{C}$ for 72 hours. The results were expressed in milligrams per organ $\left(\mathrm{mg} \mathrm{organ}^{-1}\right)$.

Cold test: performed in four samples with four subsamples of 50 seeds each, placed to germinate in rolls formed by three sheets of germitest paper, moistened with distilled water 2.5 times the dry mass of the paper. After sowing, the rolls were kept in a B.O.D. germinating chamber at $10^{\circ} \mathrm{C}$ for five days (Krzyzanowski et al., 1999). After this period of time, they were transferred to a B.O.D. chamber, regulated at $25^{\circ} \mathrm{C}$, and the evaluation was performed according to the Rules for Testing Seeds (Brasil, 2009).

Isoenzyme expression: the expression of esterase isoenzymes, acid phosphatase and peroxidase was performed on 10 seedlings obtained from the germination and cold test, being expressed through the vertical electrophoresis system in $7 \%$ of polyacrylamide gels, with application of $20 \mu \mathrm{L}$ of each sample. After the collection of the seedlings of each treatment, they were macerated separately in porcelain grains in an ice bath. The coloring systems used were described by Scandálios (1969) and Alfenas(1998). The results were analyzed visually in the gels by the presence or absence and intensity of expression of the bands.

Statistical procedure: The data were submitted to the analysis of variance by the $\mathrm{F}$ test at $5 \%$ of probability with the intention of revealing the presence of interaction between doses of gibberellic acid $x$ genotypes of beans, the quantitative factor was submitted to linear regression where it was tested the highest significant degree of the polynomial.

\section{Conclusion}

The application of increasing doses of $\mathrm{GA}_{3}$ on the aerial part of the bean plants increases the height of insertion of the first pod in both genotypes. While, the number of pods per plant and grain yield per pod was not altered by the application of $\mathrm{GA}_{3}$. The physiological quality of the seeds is affected by the doses of gibberellic acid applied to the plants. The application of $\mathrm{GA}_{3}$ on bean plants alters the isoenzymatic expression and favors the physiological performance of seeds, revealing differential effect under the genotypes evaluated in this study.

\section{Acknowledgement}

To CNPq for the grant of scholarship.

\section{References}

Albuquerque KAD, Oliveira JA, Silva PA, Veiga AD, Carvalho BO, Alvim PO, Albuquerque KAD (2010) Armazenamento e qualidade de sementes de tomate enriquecidas com micronutrientes e reguladores de crescimento. Ciência e Agrotecnologia, Lavras. 34(1):2028.

Alfenas AC (1998) Eletroforese de isoenzimas e proteínas afins: fundamentos e aplicações em plantas e microrganismos. Viçosa: ufv, p 574.

Alleoni B, Bosqueiro M, Rossi M (2000) Efeito dos reguladores vegetais de stimulate no desenvolvimento e produtividade do feijoeiro (phaseolusvulgaris L.). Publicatio, UEPG. 6:23-35.

Barendse GWM, Kepczynski J, Karssen CM, Koornneef M (1986) The role of endogenous gibberellins during fruit and seed development:studies on gibberellin-deficient genotypes of Arabidopsis thaliana. Physiol Plant. 67:315319.

Cruz HL, Ferrari CS, Meneghello GE, Konflanz V, Zimmer PD, Vinholes PS, Castro MAS (2007) Avaliação de genótipos de milho para semeadura precoce sob influência de baixa temperatura.Revista brasileira de sementes. 20(1):52-60.

Do Nascimento R,Mosquim PR (2004) Efeito do ácido giberélico e diferentes aminoácidos sobre as atividades da sintetase da glutamina e sintase do glutamato e sobre o crescimento de frutos de soja. Revista Brasil Bot. 27(1):6370.

Feucht JR, Watson DP (1958) The effect of gibberellins on internodal tissues of phaseolus vulgaris L. Amer J Bot. 45(7): 520-522.

Garcia-Martinez JL, Sponsel VM, Gaskin P (1987) Gibberellins in developing fruits of Pisum sativum cv. Alaska: studies on their role in pod growth and seed development. Planta. 170:130-137.

Graebe JE (1987) Gibberellin biosynthesis and control. Ann Rev Plant Physiol. 38:419-465.

Granjeiro PA, Veríssima CF, Aoyama H (2008) Uso da fosfatase ácida como biomarcador durante a germinação de sementes de mamona (ricinuscommunis). Engenharia Ambiental: Pesquisa e Tecnologia. 5(3):307-322.

Hooley R (1994) Gibberellins: perception, transduction and responses. Plant Mol Biol. 26:1529-1555.

Ju Z, Duan Y, Ju Z (1999) Combinations of GA3 and AVG delay fruit maturation, increase fruit size and improve storage life of 'Feicheng' peaches. J Hortic Sci Biotechnol. 74(5):579-583.

Khan MMA, Gautam C, Mohammad F, Siddiqui MH, Naeem M, Khan MN (2006) Effect of gibberellic acid spray on performance of tomato.Turk J Biol. 30:11-16.

Krzyzanowski FC, Vieira RD, França Neto JB (1999) Vigor de sementes: conceitos e testes. Londrina: abrates, 218 p.

Lange T (1998) Molecular biology of gibberellin synthesis. Planta. 204:409-419.

Leite VM, Roselem CA, Rodrigues JD (2003) Gibberellin and cytokine in effects on soybean growth. Scientia Agricola. 60:537-541.

Lima GPP, Rodrigues JD, Brasil OG (1993) Efeito de giberelina em variáveis bioquímicas durante o crescimento inicial de arroz (Oryza sativaL.) Cultivado in vitro. Iteores de açúcares redutores e proteínas. Científica.21, p. 265-274.

Metivier JR (1986) Giberelinas. In: ferri, m. G. (1986). Fisiologia vegetal. São paulo: edusp,. 2, cap. 5, p.129-16.

Modesto JC (1994) Efeitos de diferentes reguladores de crescimento sobre o desenvolvimento de porta-enxerto de citros.. 127 f. Dissertação (mestrado em fitotecnia)faculdade de ciências agronômicas, universidade estadual paulista, botucatu. 
Monselise SP (1979) The use of growth regulators in citriculture: a review. Sci Hortic. 11:30:11-16.

Nalawadi UG, Prithvi R, Krishnamurthy K (1973) Improvement in the seed germination of soybean varieties by pre-soaking treatments. Indian J Agric Sci. 43:546-550.

Pedó T, Martinazzo EG, Aumonde TZ, Villela FA (2015) Desempenho de sementes, vigor e expressão isoenzimática em plântulas de teosinto (Euchlaena mexicana schrader) sob efeito da restrição hídrica. Revista Brasileira de Biociências, Porto Alegre. 13(1):5-9.

Pereira RPW, Monteiro MBO, Abreu HS (2004) Os fitohôrmonios na formação da madeira. Floresta e Ambiente. 11(2):40-47.

Pessarakli M (2002) Role of physiology in improving crop adaptation to abiotic stresses in the tropics: the case of common bean and tropical forages.In: pessarakli, m. (ed.). Handbook of Plant and Crop Physiology.2. Ed. New york: crcpress; marceldekker, P. 583-614.

Prado NM, Dantas ACVL, Vieira EL, Almeida VO (2007) Germinação de sementes de jenipapeiro submetidas à préembebição em regulador e estimulante vegetal. Ciência e Agrotecnologia. 31:693-698.

Santes CM, Hedden P, Gaskin P, Garcia-Martinez JL (1995) Gibberellins and related compounds in young fruits of pea and their relationship to fruit-set. Phytochemistry. 40:13471355.

Santos CMR, Menezes NL, Villela FV (2004) Alterações fisiológicas e bioquímicas em sementes de feijão envelhecidas artificialmente revista brasileira de sementes, brasília. 26(1):110-119.

Sauter M, Kende H (1992) Gibberellin-induced growth and regulation of the cell division cycle in deepwater rice. Planta. Berlin. 188:362-368.

Scandálios JG (1969) Genetic control of multiple molecular forms of enzymes in plants: a review. Biochem Genet. 3(1):37-79.

Souza CA, Coelho CMM, Guidolin AF, Engelsing MJ, Bordin LC (2010) Influência do ácido giberélico sobre a arquitetura de plantas de feijão no início de desenvolvimento. Acta Scientiarum Agronomy. 32(2):325332.

Sun T, Gubler F (2004) Molecular mechanism of gibberellin signaling in plants. Ann Rev Plant Biol. 55:197-223.

Taiz L,Zeiger E (2004) Fisiologia vegetal. Porto Alegre: Artmed, 2004.

Takahashi N, Yamaguchi I, Yamane H (1988) Gibberellins. In: takahashi, n. (ed.) Chemistry of plant hormones. Boca raton: crc press, Cap. 3, p.57-151.

Valio IFM, Schwabe WW (1978) Correlative growth in seedling of phaseolus vulgaris $1 .:$ inhibition of stem growth by the primary leaves. Ann Bot. 42:263-268.

Van Huizen R, Ozga JÁ, Reinecke DM (1997) Seed and hormonal regulation of gibberellins 20-oxidase expression in pea pericarp. Plant Physiol. 115:123- 128.

Veiga AD, Von Pinho VR, Veiga AD, Pereira PHR, Oliveira KC; Von Pinho RG (2010) Influência do potássio e da calagem na composição química, qualidade fisiológica e na atividade enzimática de sementes de soja. Ciência e Agrotecnologia. 34:953-960,

Vieira EL, Castro PRC (2001) Ação de bioestimulante na germinação de sementes, vigor de plântulas, crescimento radicular e produtividade de soja. Revista Brasileira de Sementes. 23:222-228.

Vieira EL, Castro PRC, Monteiro CA (1999) Efeito de stimulate na germinação e vigor de sementes de soja. In: i congresso brasileiro de soja, londrina. Resumos. Embrapa Soja. p.361-361.

Vieira RD, Carvalho NM (1994) Testes de vigor em sementes.jaboticabal: funep, p164.

Wang Q, Zhang F, Smith D (1996) Application of $\mathrm{GA}_{3}$ and kinetin to improve corn and soybean seedling emergence at low temperature. Environ Exp Bot. 36:377-383. 